\title{
Article
}

\section{Always Already in Flux: A Response to Anne Freadman}

\author{
Charles Bazerman \\ University of California, Santa Barbara
}

Carolyn Miller's rich and theoretically complex 1984 essay “Genre as Social Action” has been widely influential among scholars who have been variously identified as part of Rhetorical Genre Studies (Freedman, 1999), North American Genre Studies (Freedman \& Medway, 1994; Artemeva, 2004), or American New Rhetorical Studies (Hyon, 1996). Despite being associated with each other, these loose congeries of scholars do not form a coherent whole with a commonly shared theory; nor have they taken up Miller's essay in exactly the same way, to use the uptake term introduced into genre discussions by Anne Freadman (1987/1994). These scholars have a variety of understandings of how contexts configure perceived communicative opportunities within situations, how communicative actions are perceived by others, how social circumstances are relevant and articulated by the participants, the degrees of freedom of action by the writer and the interpreting reader, how mandatory certain elements of genres are and how those elements are realized in texts, as well as many other issues, including the natures of agency and exigency that Freadman (2020) considers in her current essay. Moreover, the theories or concepts advanced by these scholars are developed through empirical studies, each of a different character, although Freadman would like to distinguish sharply between genre theory and genre studies.

These scholars draw on a variety of motivating problems, interdisciplinary resources, research questions, research and analytical methods, theoretical constructs, and empirical materials. They do, however, share concerns for rhetorical dynamics, the natures of situations, the semiotic mediation of social relations, and the challenges of aligning the expectations and perceptions of rhetor/writer and audience. They share a recognition of genres as existing in the attributions of participants rather than being immanent in textual forms, although the texts can provide clues or guides for attribution and models for imitation in selective features, functions, or motives. They also are all aware of and attempt to account for genre change, hybridization, migration, and polysemiousness, even though gen- 
Volume 30, 2020

http://journals.sfu.ca/cjsdw

res may be embedded in various organizational or institutional arrangements that tend to slow processes of change and limit authorial or reader degrees of freedom of action if communications are to be acceptable as effective.

For such reasons I tend to find human psychosocial processes of genre attribution (a particular form of the phenomenological process of typification, as Miller, 1984, points out) to be more fundamental and widely shared than the genre forms themselves. That is, genre terms, taxonomies of genre, representations of the characteristics of genres, instantiations of genres, responses of readers indicating their understanding of genres, and other clues to social beliefs about genre circulate socially, yet it is up to each individual to mobilize and apply particular understandings of genres in his or her production and reception of texts. Attribution processes always involve interpretation and affect consequent action-what Freadman would identify as uptake. Thus, while I have written works that might be perceived as both genre studies (for example, my studies of the evolving varieties of texts recognizable as scientific experimental reports, 1988, 1991; or as part of the production of material technology, 2000) and genre theory (such as 1994a, 1994b, 2003, 2004, 2013a, 2013b, and others, some of which I discuss below), I would see neither as my core theoretical orientation nor as my core focus. I am most fundamentally interested in writing as a mediation of human interaction. My primary concern is to help people write texts more effectively to meet their purposes and to create meanings within the social groupings that are important for their lives. This concern requires an understanding of how texts mediate action in socially organized circumstances. Within this, typification is an important sense-making process, allowing us to attribute meaning to other people's semiotic actions and to make our semiotic productions more intelligible to others. I do not attempt to identify in any taxonomic way what these semiotic or action phenomena are or attempt to attribute grounded meaning to any genre; in fact, I see genres existing only as social facts created, circulated, and given meaning in transient ways within social groupings. Genre categories are emic and not etic. Any appearance of stability or crystallization is an ongoing social accomplishment of the group-in Schryer's (1993) terms, "stabilized-for-now or stabilized enough" (p. 200). Any quasi-stability or continuity over time is also an ongoing social accomplishment. Texts can and are frequently perceived as invoking multiple or varied social types depending on the positions, interests, experiences, and interpretive frameworks of the writers and readers. High degrees of alignment are usually the work of massive social accomplishment and institutional power. Thus, I am more interested in understanding the processes by which people's typified understandings of texts are produced, circulated, and 
Volume 30, 2020

http://journals.sfu.ca/cjsdw

coordinated in social groupings-which I see as more enduring and fundamental phenomena, common to humans in their capacities to engage in social life.

Any discussion of theories held by these various scholars beyond a few general orientations, therefore, would require a careful consideration of the corpus of each scholar's work, rather than subjecting them all to a critique based on a single scholar's work. I take Freadman's (2020) discussion, consequently, specifically to be in dialogue with Carolyn Miller, who will no doubt ably articulate her own views. Other scholars may also respond in this journal to the questions raised by Freadman. I will use this occasion to articulate my own position briefly in relation to the two central concepts she raises for discussion here: agency and exigency (and, as an ancillary, a rejection of subject and subjectivity). My positions bear on these issues in ways she may not have been aware of, as she has not seemed to have engaged with the substance of my work: there is no mention of my work in either her 1987/1994 or 2002 essays and only passing mention in her current essay in the form of one footnote and one mention of a different author's use of one term I proposed.

For me, the most significant specific component of Miller's 1984 essay was the integration of rhetorical theorizing and research with phenomenological sociology through her discussion of Schutz. I had previously been engaged both with the rhetorical theory common in writing studies and with sociological theory and the sociology of science, which have phenomenological components. Miller's article gave me the linkage I needed to tie the rhetorical interest in strategic text production with the social and perceptual dynamics of interaction and social organization. This conjunction also fed into my long-standing interest in Vygotsky's theories of the formation of individual consciousness through the interaction with and use of socially experienced tools, as well as with Bakhtin's neoKantian dialogism and multivocality (see Dentith, 1995). These are all, of course, related to uptake through such topics as intersubjectivity, perception, social alignment, social facts, social formation of the mind, and internalization; accounts of all of these processes recognize that different participants have different needs, interpretations, and actions, and that coordination across participants is a problem to be understood through histories of interaction. Freadman's $(1987 / 1994,2002)$ use of the term uptake helped me articulate this problematic of multi-sided interactions further and made more explicit the linkage between Bakhtin and speech act theory (both of which, however, were already in use by a number of rhetorical scholars, myself included). Further, Freadman's 2002 discussion of the material conditions and material consequences of uptake confirmed the arguments I (1988) had made about the history, variation, use, and learning of scientific experimental reports. 
Volume 30, 2020

http://journals.sfu.ca/cjsdw

In sociology, rhetoric, and sociohistorical psychology, the issues of agency and exigency, of interest to Freadman, also have long-standing histories of discussion-along with related terms, such as motive, intent, ends, power, or object (in Vygotskian activity theory terms). For me, these discussions did not always align with Miller's articulation of the rhetorical actor or audience. Further, early on in my genre work, as I started to look at the history of scientific writing, I became aware of the fluidity of genre, the changing and varied social arrangements that genres mediated and helped modify, the creative agency of individual utterances framed within genres, and the differing perceptions of the genres invoked by any text. Given the contingency, perception, and emergent nature of situations and the understanding of texts that entered into them, I soon became enmeshed in trying to understand how even contingent good-enough-for-practical-purposes (to borrow from Garfinkel, 1967) alignment was even possible. This is a variation of the long-standing sociological question of how society is possible (Parsons, 1937).

Thus, I came to understand genre attribution as a core problem, along with how recognizable forms circulated in certain social networks so as to become sufficiently intelligible to receive good enough alignment for the tasks at hand. Any stability achieved in genre was always a social accomplishment, even though each individual would apply their personally evolving and situationally deployed understanding of types or genres, and of the features and functions they associated with them. I explicitly engaged with the problems of emergent coordination in a series of presentations around 1990 whose titles indicate the kind of problematic I was concerned with: "Difficulties in Characterizing Social Phenomena in Writing”; “Temporary Boundaries over Unstable Land Masses”; "Conceptual Change from a Sociocultural Perspective: Some Snapshots from a Family Album of Resemblances"; and, especially, "Whose Moment: the Kairotics of Intersubjectivity." These were all collected in my volume Constructing Experience (1994a). I have since then repeatedly returned to this issue of contingency, instability, and variability of perspective, within the perceptions of self, agency, events, and social arrangements, including how difficulties are exacerbated as texts move across activity systems. Indicative titles include "Singular Utterances: Realizing Local Activities through Typified Forms in Typified Circumstances" (2000); “Textual Performance: Where the Action at a Distance is” (2003); "Social Forms as Habitats for Action" (2004); "Measuring Incommensurability: Are Toxicology and Ecotoxicology Blind to What the Other Sees?" (with Rene De los Santos, 2005); and "How Does Science Come to Speak in the Courts? Citations, Intertexts, Expert Witnesses, Consequential Facts and Reasoning" (2009), among many others. I cannot review in detail all my thoughts on these matters over the years, but the most throughgoing integration of them into a larger theory of writing appear 
Volume 30, 2020

http://journals.sfu.ca/cjsdw

in my two volumes of 2013: A Rhetoric of Literate Action and A Theory of Literate Action. In both those volumes the core problem is how writers can align with readers across time and space, creating goodenough-for-the-moment shared understandings of communicative situations, actions, and meanings.

In these two volumes as earlier, in concurrence with Freadman's concerns about the implications of the concept of subject, I avoided the terms subject and subjectivity to characterize the perceptions, motives, and stances of the individual actor except when discussing an author who used the terms. Instead I used terms such as agency, act, and action. While I agree with Freadman's concerns over the term subject in relation to issues of domination and subject-object dichotomizing, I am also concerned that the terminology of subjectivity implies a stable personal consciousness or mind separated from social engagement with others, both in the immediate situation and over time. Freadman recognizes how individual action is formed within immediate social circumstance, defined by jurisdictions (her current term to cover social groupings and arrangements, as providing the context for ritualized ceremonies or games, which she had already associated with genres, as in Freadman, 1987/1994). I, however, from my understanding of Vygotsky, Volosinov, Bakhtin, and pragmatists such as G. H. Mead and Harry Stack Sullivan, consider a longer-term formation of an individual in dynamic experiential relation with others, using socially learned tools of language, semiosis, and artifacts that provide resources for action in any particular circumstances. Experiences using these tools over time create a series of perceptions, orientations, responses, and repertoires that evolve gradually through life and therefore create something like a recognizable self entering into any particular situation. Further, the individual brings biologic, social, and psychological needs to the circumstances, which also condition motives and actions. While the word subjectivity does not capture well this evolving, interactive, and somewhat plastic individuality, actors do bring their own sensemaking, motives, practices, and habituated action choices to situations.

As a teacher of writing, I find it particularly important to attend to what people bring from their lives and prior experiences to each situation that can motivate them to formulate and elaborate their meanings, needs, semiotic actions, social roles, and identities that will help them continue to interact, communicate, and evolve with others. This also means that as they move among social groups, they do not need to leave all their prior experience, perceptions, motives, or plans at the door. Rather they have the potential to make their mark on the discourse, meanings, social arrangements, and practices realized within situations through the creation of new statements which may be accepted and taken up by others. Each text as a new instantiation of a genre (or multiple hybridized genres) can both carry the genre forward and/or transform it-in turn evolving the social arrangements. Texts need 
Volume 30, 2020

http://journals.sfu.ca/cjsdw

to be intelligible and meaningful within the typifications of the domain, but they also create meanings to serve the needs of the individual, even in the most regulated and resistant-to-change social arrangements.

Freadman (2020) recognizes in her current essay the forces for change in genre and social organizational change when she identifies exigence as a product of the individual's uptake of events and needs, noting that "the actor has a purpose; what she achieves may not be conventional at all" (p. 121). She further notes that her "use of the term [exigence] will be restricted to the occasion of the implementation of rhetorical decisions in order to intervene in social affairs. This suits the account I (2012) have given of a contested rhetorical situation; it also suits the account I give of uptake" (p. 121). However, she goes on to note that "I insist that uptake is less a matter of subjective purpose than it is governed dynamically by the changing conditions of play" (p. 121). Yet she still needs some way to account for the individual's perspective and position, beyond the momentary state of play. In this respect, she might find interesting Ryan Dippre's (2019) uptake of ethnomethodology to consider how writers develop through learning to address the "what comes next" in each writing situation they encounter, elaborated in his recent book Talk, Tools, and Texts.

Further, in recognizing that identification of exigence is itself a kind of uptake, Freadman recognizes that exigence is not determined by fixed social structures, but rather sees such apparent structures, even the most regulated, as evolving from the series of exigences taken up and realized in actions, with no ultimate authority being fundamentally constitutive over the long term. In this way, although she rejects structuralism, she seems to be moving towards some version of structurationalism where structures are the ongoing accomplishment of actors (see, for example, Giddens, 1984). This is certainly the view I have taken.

In sum, I am in accord with Freadman contemplating the fluidity, contingency, and multivalency of genre, social arrangements, moments, exigency, and agency. Her earlier work forcefully demonstrated how genre was tied to compelling action in highly structured and regulated systems, such as the judicial and penal systems. Her 1987/1994 essay brought into sharp relief the potential consequentiality of genre when located within compelling systems under the right time and circumstances with authorized speakers-all meeting felicity conditions, in Austin's speech act terminology (Austin, 1962). In her 1987/1994 essay the term ceremony was used to characterize the highly organized social arrangements and social action brought about through the social means of appropriately produced genres in the circumstances. Further, in her 2002 essay she highlighted how agency was embodied in well-defined roles of people acting in their official capacity within those systems to respond 
Volume 30, 2020

http://journals.sfu.ca/cjsdw

to situations and motives that seem to make exigencies apparent, such as the need to punish convicted criminals as certified by a court proceeding, which creates the need to determine and carry out the punishment (Freadman, 2002).

Now she is considering less compulsory arrangements and situations, so seeks a more complex and fluid vocabulary to deal with less stark circumstances, which leads her to supplement ceremony with jurisdiction to characterize social arrangements. Yet even the starkest of circumstances and the most entrenched ceremonies within regulated jurisdictions change, evolve, and provide some degrees of freedom for actors to seek various outcomes. They also are complexly related to other domains or jurisdictions, as Russell maps out in his considerations of activity systems implicated in student assignments in a cell biology class (Russell, 1997). So I concur with her exploration of terms that will be able to characterize the more difficult and fuzzy cases that our writing engages as we move through protean multiple social arrangements. In this movement we as writers may push the boundaries of various social arrangements, in order to meet our own needs and desires within circumstances, even as we reformulate our ends within what we perceive as the available possibilities of circumstances. We also adjust to how others seem to perceive, pick up on, and respond to our productions, in an emergent and ever-evolving process of semiotic life in interaction with relevant others.

\section{References}

Artemeva, N. (2004). Key concepts in rhetorical genre studies. Technostyle, 20(1), 3-38.

Austin, J. L. (1962). How to do things with words. Oxford, UK: Oxford University Press.

Bazerman, C. (1988). Shaping written knowledge: The genre and activity of the experimental article in science. Madison: University of Wisconsin Press.

Bazerman, C. (1991). How natural philosophers can cooperate: The literary technology of coordinated investigation in Joseph Priestley's History and Present State of Electricity (1767). In C. Bazerman \& J. Paradis (Eds.), Textual dynamics of the professions: Historical and contemporary studies of writing in professional communities (pp. 13-44). Madison: University of Wisconsin Press. Retrieved from https://wac.colostate.edu/docs/books/textual_dynamics/chapter1.pdf

Bazerman, C. (1994a). Constructing experience. Carbondale, IL: Southern Illinois University Press. Bazerman, C. (1994b). Systems of genres and the enactment of social intentions. In A. Freedman \& P. Medway (Eds.), Genre and the new rhetoric (pp. 79-101). London, UK: Taylor \& Francis. 
Volume 30, 2020

http://journals.sfu.ca/cjsdw

Bazerman, C. (2000). Singular utterances: Realizing local activities through typified forms in typified circumstances. In A. Trosborg (Ed.), Analysing professional genres (pp. 25-40). Amsterdam, The Netherlands: John Benjamins.

Bazerman, C. (2003). Textual performance: Where the action at a distance is. JAC: A Journal of Composition Theory, 23(2), 379-396.

Bazerman, C. (2004). Social forms as habitats for action. Journal of the Interdisciplinary Crossroads, 1(2), 317-333.

Bazerman, C. (2009). How does science come to speak in the courts? Citations, intertexts, expert witnesses, consequential facts, and reasoning. Law and Contemporary Problems, 72(1), 91-120.

Bazerman, C. (2013a). A rhetoric of literate action: Literate action volume 1. Fort Collins, CO: The WAC Clearinghouse, 2013. Retrieved from https://wac.colostate.edu/docs/books/literateaction/v1/rhetoric.pdf

Bazerman, C. (2013b). A theory of literate action: Literate action volume 2. Fort Collins, CO: The WAC Clearinghouse. Retrieved from https://wac.colostate.edu/docs/books/literateaction/v2/theory.pdf

Bazerman, C., \& De los Santos, R. A. (2005). Measuring incommensurability: Are toxicology and ecotoxicology blind to what the other sees? In R. A. Harris (Ed.), Rhetoric and incommensurability (pp. 424-463). West Lafayette, IN: Parlor Press.

Dentith, S. (1995). Bakhtinian thought: An introductory reader. London, UK: Routledge.

Dippre, Ryan J. (2019). Talk, tools, and texts: A logic-in-use for studying lifespan literate action development. Fort Collins, CO: The WAC Clearinghouse. Retrieved from https://wac.colostate.edu/books/practice/talk/

Freadman, A. (1994). Anyone for tennis? In A. Freedman \& P. Medway (Eds.), Genre and the new rhetoric (pp. 43-66). London, UK: Taylor \& Francis. (Reprinted from The place of genre in learning: Recent debates, pp. 91-124, by I. Reid, Ed., 1987, Geelong, Australia: Centre for Studies in Literary Education, Deakin University)

Freadman, A. (2002). Uptake. In R. Coe, L. Lingard, \& T. Teslenko (Eds.), The rhetoric and ideology of genre: Strategies for stability and change (pp. 39-53). Cresskill, NJ: Hampton Press.

Freadman, A. (2020). A tardy uptake. Canadian Journal for Studies in Discourse and Writing/Rédactologie, 30, 105-132. doi: 10.31468/cjsdwr.781

Freedman, A. (1999). Beyond the text: Towards understanding the teaching and learning of genres. TESOL Quarterly, 33(4), 764-767. doi:10.2307/3587890 
Volume 30, 2020

http://journals.sfu.ca/cjsdw

Freedman, A., \& Medway, P. (1994). Locating genre studies: Antecedents and prospects. In A. Freedman \& P. Medway (Eds.), Genre and the new rhetoric (pp. 1-20). London, UK: Taylor \& Francis.

Garfinkel, H. (1967). Studies in ethnomethodology. Englewood Cliffs, NJ: Prentice-Hall.

Giddens, A. (1984). The constitution of society: Outline of the theory of structuration. Cambridge, UK: Polity Press.

Hyon, S. (1996). Genre in three traditions: Implications for ESL. TESOL Quarterly, 30(4), 693-722. doi: $10.2307 / 3587930$

Miller, C. R. (1984). Genre as social action. Quarterly Journal of Speech, 70(2), 151-167. doi:10.1080/00335638409383686

Parsons, T. (1937). The structure of social action: A study in social theory with special reference to a group of recent European writers. New York, NY: McGraw-Hill.

Russell, D. R. (1997). Rethinking genre in school and society: An activity theory analysis. Written Communication, 14(4), 504-554. doi:10.1177/0741088397014004004

Schryer, C. F. (1993). Records as genre. Written Communication, 10(2), 200-234.

doi:10.1177/0741088393010002003 